CZASOPISMO INŻYNIERII LĄDOWEJ, ŚRODOWISKA I ARCHITEKTURY JOURNAL OF CIVIL ENGINEERING, ENVIRONMENT AND ARCHITECTURE

JCEEA, t. XXXIII, z. 63 (3/16), lipiec-wrzesień 2016, s. 185-192

\author{
Ada KOWALSKA ${ }^{1}$ \\ Karolina KURTZ-ORECKA ${ }^{2}$
}

\title{
ANALIZA DOBRYCH PRAKTYK W ZAKRESIE WYKORZYSTANIA OZE ORAZ ENERGII ODPADOWEJ NA PRZYKŁADZIE ROZWIĄZAŃ OBIEKTU PRZEMYSLOWO-BIUROWEGO W SCHWABACH/ NIEMCY
}

\begin{abstract}
Zastosowanie źródeł odnawialnych i niekonwencjonalnych na cele zaspokojenia potrzeb energetycznych pozwala na ograniczenie kosztów zakupu energii oraz opłat za korzystanie ze środowiska naturalnego w przypadku obiektów przemysłowych. W artykule omówiono rozwiązania służące redukcji zużycia energii i wykorzystaniu energii odpadowej generowanej w procesach produkcyjnych, zastosowane w nowej siedzibie producenta maszyn w przemyśle kablowym, firmie NIEHOFF. Zastosowane technologie pozwoliły na ograniczenie kosztów zakupu energii, opłat za korzystanie ze środowiska naturalnego oraz sprawiło, że firma NIEHOFF stała się jednym z największych użytkowników geotermii w Niemczech. Zastosowane nowatorskie rozwiązania, wymagały użycia materiałów i izolacji termicznej o możliwie najniższych współczynnikach przewodzenia ciepła. Dopiero tak zaprojektowany budynek mógł spełnić warunki wysokiej efektywności energetycznej nowobudowanych obiektów. Głównym źródłem ciepła w budynku jest energia geotermalna, która zasila zarówno układ ogrzewania jak i chłodzenia. Takie podejście pozwoliło na oszczędności rzędu 75\% w porównaniu do rozwiązań konwencjonalnych. Technologia wykorzystana do kontroli obiektów dostosowuje temperatury w pomieszczeniach $\mathrm{z}$ uwagi na warunki wewnętrzne oraz zewnętrzne, co zostało osiągnięte dzięki stałemu wglądowi do danych pogodowych. Zaopatrzenie w ciepło/chłód technologiczny zachodzi przez radiacyjne panele sufitowe, sufitowe panele grzewcze i wentylację oraz tradycyjną instalację c.o. co znacznie podniosło efektywność grzewczą oraz podniosło komfort pracowników. Obiekty firmy NIEHOFF w Schwabach są przykładem dobrych praktyk proekologicznych i zrównoważonego wykorzystywania energii.
\end{abstract}

Słowa kluczowe: energia odnawialna, środowisko naturalne, energooszczędne budownictwo przemysłowe, efektywne oszczędzanie, inteligentne budynki

\footnotetext{
${ }^{1}$ Autor do korespondencji / corresponding author: Ada Kowalska, Zachodniopomorski Uniwersytet Technologiczny w Szczecinie, Wydział Budownictwa i Architektury, al. Piastów 50, 70-311 Szczecin; tel.668208638; adaakowalska@gmail.com

${ }^{2}$ Karolina Kurtz-Orecka (opiekun naukowy), ZUT w Szczecinie, Katedra Fizyki Budowli i Materiałów Budowlanych, tel.608691975, karolinakurtz@gmial.com
} 


\section{Wprowadzenie}

Problematyka nadmiernego wykorzystywania nieodnawialnych surowców energetycznych na cele ogrzewania i wentylacji oraz wpływu ich spalania na środowisko naturalne poruszana jest od lat i znalazła odzwierciedlenie nie tylko w doniesieniach naukowych, ale również obowiązującym prawie europejskim m.in. w dyrektywie w sprawie charakterystyki energetycznej budynków [2] oraz dyrektywie w sprawie emisji przemysłowych [3]. Po dzień dzisiejszy głównymi źródłami energii w gospodarstwach domowych, przemyśle oraz budynkach użyteczności publicznej, w Polsce i na świecie, są nieodnawialne źródła energii.

Według danych [4] zużycie energii końcowej przez przemysł w 2013 r. wyniosło 276,6 Mtoe, co stanowi $25,10 \%$ całkowitego zużycia energii w Europie. W samych Niemczech wielkość zużycia energii w przemyśle wynosi 60,74 Mtoe - 22\% w skali zużycia w całej Unii, zaś w Polsce sięga 15,10 Mtoe [4].

Rozwiązania służące oszczędnością energii stosowane są przede wszystkim w budynkach mieszkalnych, zaś dość rzadko w obiektach przemysłowych głównie z uwagi na ich specyficzne warunki użytkowania i potrzeby technologii charakteryzujące dany sektor przemysłu, jednak obiekty te nie są zwolnione z konieczności podnoszenia swojej efektywności energetycznej. Przykładem dobrej praktyki w tym zakresie jest energooszczędny budynek firmy poligraficznej z Karlsruhe [6], w którym zastosowany oryginalny kształt budynku oraz innowacyjny system chłodzenia, pozwoliły na znaczne zredukowanie zużycia energii. Ponadto zintegrowany system chłodzenia z odzyskiem chłodu przyczynił się do zmniejszenia zapotrzebowania na energię o prawie $90 \%$ [6].

Jednym ze sposobów wpływania na poprawę stanu środowiska naturalnego jest przenoszenie na grunt rodzimy sprawdzonych, często innowacyjnych, rozwiązań efektywnych energetycznie, tzw. dobrych praktyk.

Polska, podobnie jak i inne kraje europejskie, zobligowana jest do realizacji polityki unijnej w zakresie ochrony środowiska naturalnego, w tym obniżenia limitów emisji zanieczyszczeń powietrza. Wskazane dla wspólnoty nowe pułapy redukcji emisji zanieczyszczeń do osiągnięcia do roku 2020, są rygorystyczne a ich uzyskanie wymaga podjęcia zdecydowanych działań w każdym sektorze gospodarki oraz istotnego zwiększenia wykorzystania odnawialnych i niekonwencjonalnych źródeł energii [7]. Według raportu Europejskiej Agencji Środowiska [1] Polska i Niemcy są krajami, w których na przestrzeni ostatniej dekady emisja zanieczyszczeń do środowiska naturalnego uległa wzrostowi.

Przykładem dobrej praktyki w poszukiwaniu rozwiązań minimalizujących wpływ przemysłu na środowisko naturalne są rozwiązania podjęte podczas rozbudowy podstawowego zakładu, przez niemieckiego producenta maszyn - firmę NIEHOFF. 


\section{Firma NIEHOFF}

Działająca na rynku niemieckim od 1951 r. firma NIEHOFF, Schwabach, jest jednym z wiodących, ogólnoświatowych dostawców maszyn w przemyśle kablowym. W jej ofercie mieści się wykonywanie projektów maszyn pod klucz oraz globalna obsługa dostarczanych produktów. Na przestrzeni lat rosło zapotrzebowanie na powierzchnię produkcyjną i biurową. W 2007 r. zlecono wykonanie opracowania koncepcji i realizacji nowego kompleksu obiektów, a rok później rozpoczęto prace budowlane pierwszego etapu inwestycji. Całe przedsięwzięcie zajęło 8 lat. W grudniu 2015 r. ostatni etap inwestycji został zakończony i oddany do użytkowania (rys. 1,2) [9]. Całkowita powierzchnia nowej siedziby firmy to 35,5 tys. $\mathrm{m}^{2}$, z czego 25 tys. $\mathrm{m}^{2}$ stanowi część produkcyjną, w której mieszczą się hale $\mathrm{z}$ liniami technologicznymi, lakiernia oraz pomieszczenia magazynowe. Pozostała powierzchnia pełni funkcje zaplecza socjalno-biurowego.

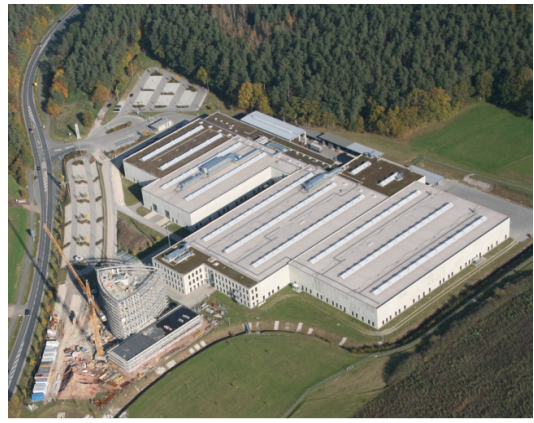

Rys. 1. Widok na kompleks zabudowań [9]

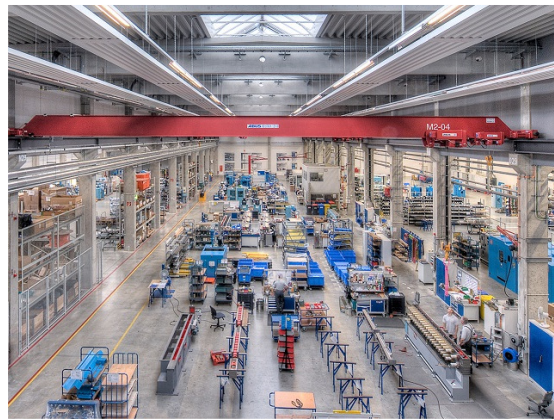

Rys. 2. Widok na główną halę produkcyjną [9]

Fig. 1. Aerial view on a complex of buildings [9] Fig. 2. View of the main production hall [9]

\section{Najlepsze praktyki - prezentacja zastosowanych rozwiązań}

Głównym celem, przyświecającym koncepcji budowy nowej siedziby firmy NIEHOFF, było ograniczenie kosztów zakupu energii oraz zmniejszenie opłat za korzystanie ze środowiska naturalnego. Osiągnięto to przez wprowadzenie zintegrowanego zarządzenia energią. Zastosowaną w obiekcie technologię ogrzewania i chłodzenia oparto na wykorzystaniu energii geotermalnej oraz instalację pomp ciepła. Podstawowym warunkiem, pozwalającym na osiągnięcie wysokiej efektywności energetycznej nowych budynków, była odpowiednia izolacja termiczna przegród zewnętrznych oraz instalacji. Przegrody zewnętrze budynku produkcyjnego wykonano z izolowanego termicznie betonu kompozytowego, osiągając współczynnik przenikania ciepła elewacji poniżej $0,23 \mathrm{~W} /\left(\mathrm{m}^{2} \mathrm{~K}\right)$ oraz $0,16 \mathrm{~W} /\left(\mathrm{m}^{2} \mathrm{~K}\right) \mathrm{w}$ przypadku stropodachu izolowanego wełną mineralną o grubości $20 \mathrm{~cm}$, co pozwoliło na spełnienie restrykcyjnych niemieckich wymagań w zakresie ograniczenia ilości energii koniecznej do dostarczenia na potrzeby ogrzewania i chłodzenia. 


\subsection{Energia geotermalna}

Ograniczenia zużycia energii końcowej i pierwotnej na cele ogrzewania i chłodzenia w budynku fabrycznym uzyskano przez zastosowanie 160 pionowych sond wprowadzonych do rzędnej $80 \mathrm{~m}$ pod poziomem terenu - ograniczone zagłębienie narzuciły warunki lokalnego prawa geologicznego i górniczego. Pobierana z gruntu energia zasila 2 pompy ciepła, które zasilane energią geotermalną pokrywają $75 \%$ zapotrzebowania na energię cieplną oraz $85-100 \%$ zapotrzebowania chłód technologiczny. Pobrana energia podlega częściowej akumulacji w magazynach energii. W przypadku wyłącznego zapotrzebowania na chłodzenie system nie generuje prawie żadnych kosztów, poza zapotrzebowaniem na energią elektryczną potrzebną do zasilenia urządzeń pomocniczych, a chłodzenie całkowicie pokrywane jest energią geotermalną. Dodatkowo, do magazynu ciepła doprowadzona jest instalacja składająca się z 5 kompresorów i kondensacyjny kocioł gazowy. Zadaniem kompresorów jest dostarczenie sprężonego powietrza do obszarów roboczych linii produkcyjnych. Energia odpadowa, uzyskana z procesów technologicznych w fabryce, wykorzystywana jest do podgrzewania ciepłej wody użytkowej oraz wspomaga instalację grzewczą. Szczytowe źródło ciepła - gazowy kocioł kondensacyjny, zasila instalację grzewczą budynku fabryki, gdy temperatura zewnętrzna spadnie poniżej $5^{\circ} \mathrm{C}$.

\subsection{Ogrzewanie i chłodzenie}

Ogrzewanie samej lakierni również oparte jest na spalaniu gazu zimnego, natomiast do ogrzewania budynku administracyjnego zastosowano lekki olej opałowy. W budynku tym ciepło/chłód, dostarczane jest do pomieszczeń ogrzewanych poprzez radiacyjne panele sufitowe, ogrzewanie powierzchniowe zainstalowane na powierzchni sufitów, układy wentylacji mechanicznej z klimatyzacją oraz z wykorzystaniem tradycyjnej instalacji c.o. (w niektórych pomieszczeniach). Chłodzenia wymagają urządzenia linii technologicznych, emulsja wykorzystywana w procesach ciągnienia drutu, a także pomieszczenia serwerów.

$\mathrm{Na}$ terenie hali produkcyjnej oraz w korytarzach budynku biurowego, zapotrzebowanie na ciepło i chłód pokrywane jest za pomocą radiacyjnych paneli sufitowych. Promieniujące w dół ciepło zapewnia niemal pionowy gradient temperatury, który jest niemożliwy do osiągnięcia, na terenie hal produkcyjnych, przy rozwiązaniach tradycyjnych. Zastosowany system spełnia rolę klimatyzacji w cieplejsze dni. Kontrola temperatury w pomieszczeniach odbywa się automatycznie z wykorzystaniem inteligentnego systemu sterowania, współpracującego $\mathrm{z}$ automatyką pogodową. W porównaniu do ogrzewania podłogowego, radiacyjne panele sufitowe działają bardzo szybko na zmiany temperatury - pierwsze efekty odczuwalne są już po 10 minutach od włączenia ogrzewania. Regulacja warunków termicznych w pomieszczeniach biurowych w budynku administracyjnym oraz części fabrycznej, odbywa się za pomocą sufitowych paneli grzewczych oraz systemu wentylacji, znajdującego się w podłodze pomieszczeń (rys. 3). 


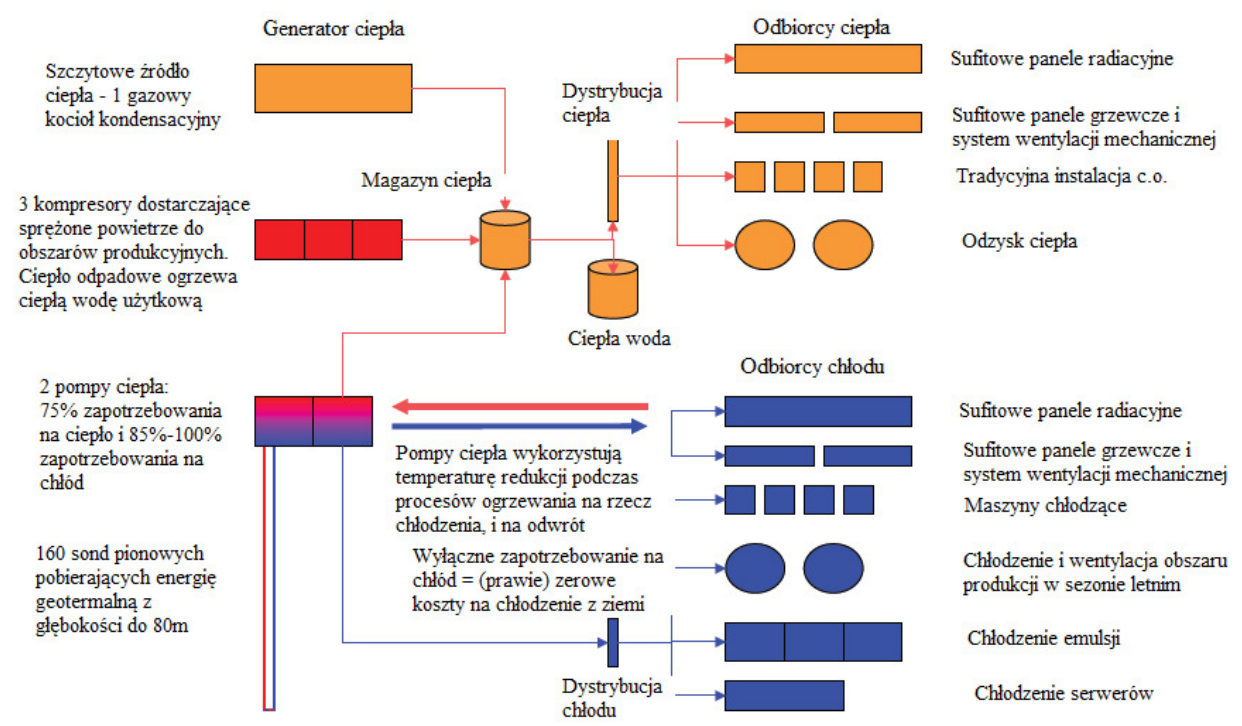

Rys. 3. Schemat instalacji grzewczo-chłodzącej [9]

Fig. 3. Scheme of heating and cooling systems [9]

Budynek administracyjno-biurowy w rzucie poziomym, ma kształt wyoblonego trójkąta równobocznego. Łagodne przejście jednej ściany zewnętrznej w drugą zapewniło usunięcie wystąpienia liniowych mostków termicznych na styku ściana - ściana. Z wyłączeniem parteru, wszystkie kondygnacje są powtarzalne. Powierzchnia danego piętra została podzielona na dwa obszary logistyczne: część biurową oraz rdzeń (komunikacja i pomieszczenia sanitarne).

\subsection{Oświetlenie pomieszczeń}

Pomieszczenia administracyjne w dużym stopniu oświetlane są światłem dziennym. Dla zapewnienia normowych wartości oświetlenia w obszarach roboczych, wbudowano oświetlenie LED-owe. Czujniki światła dziennego regulują natężenie dostarczanego oświetlenia, co zmniejsza zużycie energii elektrycznej o ok. 30\% w stosunku do systemów konwencjonalnych. Zainstalowane automatyczne rolety fasadowe zmieniając swoje ustawienie w zależności od intensywności padania promieni słonecznych na powierzchnię okna, chronią budynek przed przegrzaniem oraz powstaniem zjawiska olśnienia (rys. 4).

$\mathrm{Z}$ uwagi na komfort użytkowników budynku, zaprojektowane oświetlenie w przypadku wystarczającej ilości naturalnego światła, pracuje z najniższą intensywnością. Rdzeń budynku nie ma dostępu do światła dziennego. Całkowite zapotrzebowanie na światło w korytarzach i sanitariatach pokrywane jest przez oświetlenie wbudowane z LED-owymi źródłami oświetlenia. 


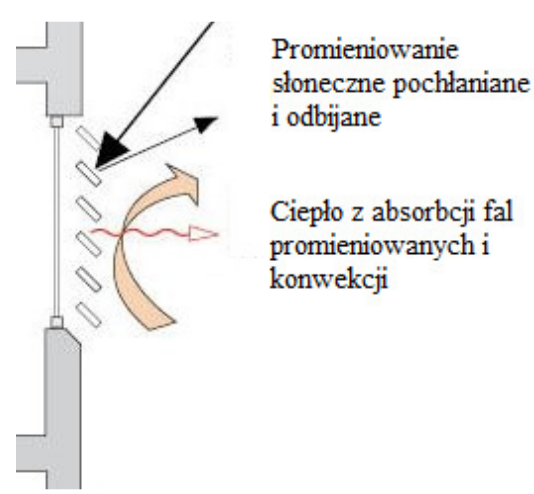

Rys. 4. Schemat działania rolet fasadowych, na podstawie [5]

Fig. 4. Shade facade flow chart, based on [5]

System odpowiedzialny za kontrolę temperatury w budynkach i ustawienie rolet okiennych zlokalizowany jest na dachu budynku administracyjnego. Stałe połączenie $\mathrm{z}$ bieżącymi danymi o warunkach panujących $\mathrm{w}$ środowisku zewnętrznym, ma na celu zapewnić czas na zmianę ustawień, których efekty odczuwalne są po 48 godzinach.

\subsection{Odzysk ciepła}

W celu zwiększenia efektywności energetycznej hali produkcyjnej, zainstalowano nowoczesny system wentylacji oraz maszyny $z$ indywidualną instalacją wymiennika ciepła. Zastosowane urządzenia $\mathrm{w}$ znacznym stopniu przyczyniły się do poprawy jakości powietrza. Energia zawarta w zużytym powietrzu z systemu wentylacji i lakierni - z procesu suszenia, wykorzystywana jest do wstępnego podgrzania świeżego powietrza. Odzysk ciepła z powietrza wywiewanego za pomocą krzyżowego wymiennika ciepła, daje oszczędność energii cieplnej na poziomie $60-75 \%$. Kabiny suszenia w malarni są obsługiwane w trybie recyrkulacji świeżego powietrza, który spowodował nieznaczne straty wyciągowe podczas pracy. Izolacja termiczna kabin grubości $120 \mathrm{~mm}$ przyczyniła się do ograniczenia strat ciepła do minimum oraz zmniejszenia zapotrzebowania na energię hali produkcyjnej.

\subsection{Wielkość zużycia energii w budynku fabrycznym}

Wykorzystanie odnawialnych źródeł energii oraz energii odpadowej przyczyniło się do osiągnięcia wskaźnika zużycia energii pierwotnej przez budynek fabryczny na poziomie $190 \mathrm{kWh} /\left(\mathrm{m}^{2}\right.$ rok). Przy dopuszczalnej wartości wskaźnika zapotrzebowania na nieodnawialną energię pierwotną $E P=347 \mathrm{kWh} /\left(\mathrm{m}^{2} \mathrm{rok}\right)$, daje to $45 \%$ dopuszczalnego zużycia zgodnie z niemieckimi standardami. Na rysunku 5 przedstawiono zużycie oleju opałowego na cele ogrzewania w starej siedzibie firmy NIEHOFF, zaś na rysunku 6 wskaźniki energii cieplnej zgodnie z wytycznymi VDI3807 [8] „Wartości zużycia w budynkach”. 
Zużycie oleju opałowego w kWh

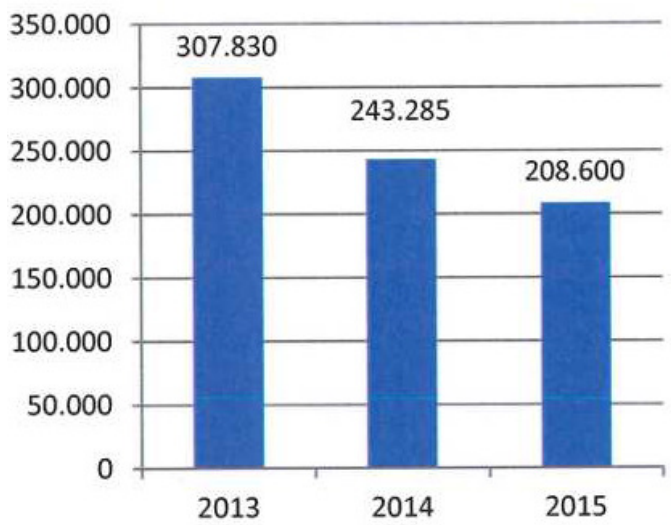

Rys. 5. Zużycie oleju opałowego na cele ogrzewania w starej siedzibie firmy, na podstawie [10]

Fig. 5. Consumption of fuel oil for heating purposes in the old headquarters, based on [10]

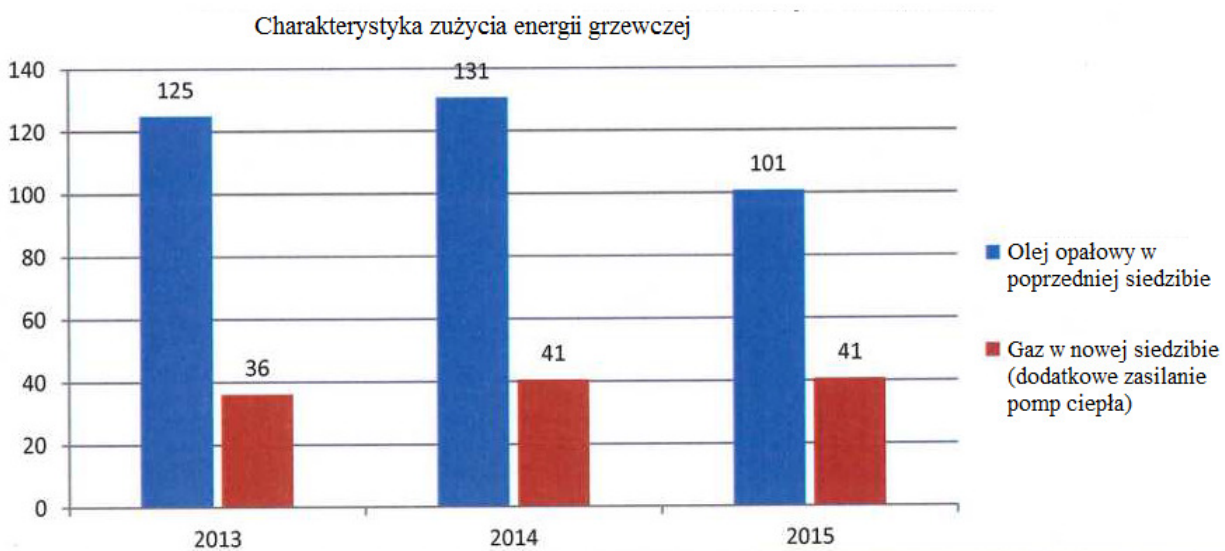

Rys. 6. Wskaźniki energii cieplnej zgodnie z wytycznymi VDI3807 [8], na podstawie [10]

Fig. 6. Indicators of thermal energy according to VDI3807 [8], based on [10]

\section{Podsumowanie}

W zaledwie 6 lat firma NIEHOFF wybudowała budynek fabryczny i administracyjny, spełniający najwyższe wymagania $\mathrm{z}$ uwagi na energooszczędność nowobudowanych obiektów. Jest to trend ogólnoświatowy, który nie dotarł jeszcze na Polski rynek budownictwa przemysłowego. Coraz bardziej rygorystyczne przepisy narzucane przez prawo europejskie, spowodują wzrost wykorzystywania odnawialnych źródeł energii i budowę tego typów obiektów w Polsce. Firma NIEHOFF jest dobrym przykładem zastosowania rozwiązań zapewniających zrównoważone wykorzystywanie energii. 


\title{
Literatura
}

[1] Air quality in Europe - 2015 report.

[2] Dyrektywa Parlamentu Europejskiego i Rady 2010/31/UE z dnia 19.05.2010 r., w sprawie charakterystyki energetycznej budynków, Dz.U. UE L153/13.

[3] Dyrektywa Parlamentu Europejskiego i Rady 2010/75/UE z dnia 24.11.2010 r. w sprawie emisji przemysłowych - IED, (zintegrowane zapobieganie zanieczyszczeniom i ich kontrola), Dz.U. L 257 z 10.10.1996, s. 26.

[4] Energy statistical pocketbook. https://ec.europa.eu \{ dostęp 23.05.2016\}.

[5] http://www.australianliving.com.au \{dostęp 10.05.2016\}.

[6] http://www.efficiency-from-germany.info \{dostęp 20.05.2016\}.

[7] http://www.gios.gov.pl \{dostęp 16.05.2016\}.

[8] https://www.vdi.de \{dostęp 23.05.2016\}.

[9] NIEHOFF Magazine, http://www.niehoff-gmbh.info/ \{dostęp 23.05.2016\}.

[10] Umwelterklärung 2016 für 2015.

\section{ANALYSIS OF GOOD PRACTICE IN THE USE OF RES AND WASTE ENERGY FOR EXAMPLE OF BUILDING INDUSTRY OFFICE IN SCHWABACH/ GERMANY}

\begin{abstract}
S u m m a r y
The use of renewable and alternative sources for the purposes of energy needs allows to reduce costs of energy purchase and fees for use of the environment in industrial facilities. The solutions to reduce the energy consumption and the use of waste energy generated in the manufacturing processes used in the new building of machine manufacturer in the cable industry, the NIEHOFF company have been discussed in the article.

The use of unconventional sources has allowed to reduce the cost of energy purchase, charges for the use of the environment and made NIEHOFF company one of the largest users of geothermal energy in Germany. A range of innovative solutions has required the use of materials and thermal insulation with the lowest possible heat conductivity coefficients. Such a designed building could meet the conditions of the high energy efficiency of new buildings. The main source of heat in the building is geothermal energy that powers both the heating and cooling. This approach has allowed savings of $75 \%$ compared to conventional solutions. The technology used to control objects adjusts the room temperature due to the conditions, internal and external, which has been achieved through continuous insight into weather data. Heat supply / cooling technology occurs by radiation ceiling panels, heating ceiling panels, ventilation and a traditional installation C.O. which has greatly increased the efficiency of heating and increased the comfort of employees.

Objects of NIEHOFF in Schwabach are an example of good pro-ecological practices and sustainable use of energy.
\end{abstract}

Keywords: renewable energy, the environment, energy-efficient industrial building, economize, intelligent buildings

DOI:10.7862/rb.2016.200

Przestano do redakcji: $06.06 .2016 r$.

Przyjęto do druku: 30.11.2016 $r$. 